\title{
Performance measuRement In SMALL AND MEDIUM ENTERPRISES: SOUTH AFRICAN ACCOUNTANTS’ VIEW
}

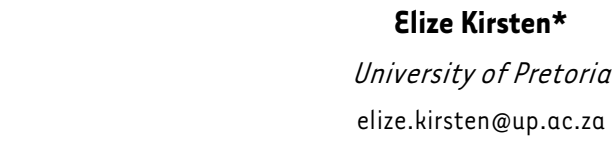

\section{Frans Vermaak"}

University of Pretoria

frans.vermaak@up.ac.za

Received: February 2014

\author{
Elize Kirsten* \\ elize.kirsten@up.ac.za
}

\author{
Hendrik Wolmarans+ \\ University of Pretoria \\ hendrik.wolmarans@up.ac.za
}

Accepted: August 2014

\begin{abstract}
Small and Medium Enterprises (SMEs) are important catalysts of economic growth, creating employment opportunities and contributing to the gross domestic product (GDP) of their respective countries. Unfortunately, SMEs suffer from a high failure rate due to SME managers' lack of managerial knowledge and skills. SME managers also do not use performance measures which are important in business management and provide support to the managers in decision-making processes. This study contributes to the existing knowledge by determining that the use of a performance measurement tool is important in SMEs, as it can help to improve their performance and chances of survival. Accountants have the knowledge and skills to help SMEs to measure their performance and to achieve their business objectives. Accountants calculate financial ratios, explain the results and provide advice to SMEs. They, however, do not develop a Balanced Scorecard, although they perceive it to be beneficial to the SMEs.
\end{abstract}

Keywords

Small and medium enterprises (SMEs), performance measurement, financial ratios, Balanced Scorecard, Accountants

\footnotetext{
*Ms $\varepsilon$ Kirsten is a master's student in the Department of Financial Management, University of Pretoria, South Africa. \#Prof FNS Vermaak is a professor in the Department of Financial Management, University of Pretoria, South Africa. +Prof HP Wolmarans is a professor in the Department of Financial Management, University of Pretoria, South Africa.
} 


\section{INTRODUCTION}

Small and medium enterprises (SMEs) play an important role in the global economy. SMEs are recognised as economic growth drivers, locally and globally. Some of the roles SMEs fulfil include creating job opportunities and introducing innovation and entrepreneurial skills (National Credit Regulator [NCR], 2011:7). According to Abor and Quartey (2010:223), SMEs contribute roughly $50 \%$ of South Africa's GDP, and $60 \%$ of those employed in South Africa are employed by SMEs.

The classification criteria applied in determining whether an enterprise is to be classified as a SME or not, can vary from number of employees and annual turnover to gross fixed assets or number of products produced in a year (South African Revenue Service [SARS], 2010; Income Tax Act No. 58 of 1962). The purpose for which the business is classified determines the definition used, as the regulations and regulatory bodies' interpretation thereof differ for each situation and industry. The National Small Business Amendment Act No. 26 of 2003 has numerous criteria to define a SME, but in general a business is classified as a SME if that business has fewer than 50 full-time employees, a total annual turnover of R13m or less and total gross assets of less than R5m.

The average life of small businesses has historically been measured as being less than five years (Patrone \& duBois, 1981:35). Even more recently, SMEs have continued to suffer from a high failure rate (Fatoki, 2012:180). There are a multitude of factors that contribute to these devastating statistics. The lack of credit, mismanagement and high production costs are the tip of the iceberg. Often SMEs are family businesses that started where a need in the market was identified. As a result, the SME owners/managers (hereafter referred to as SME managers) are experts in the product or service they deliver, but with little or no knowledge of business or financial management (Voulgaris, Doumpos \& Zopounidis, 2000:128).

A business's chance for survival, and ultimately its success, is determined by a multitude of different factors. One such factor is the effectiveness of management decision-making (Thomas \& Evanson, 1987:555). Performance measurement is important in terms not only of managing the business, but particularly through supporting managers in the decision-making processes. Performance measures are used by firms to evaluate, control and improve processes to ensure that their objectives are achieved (Ghalayini \& Noble, 1996:63).

A vital part of an in-depth assessment of a business's performance is the evaluation of the financial position of the firm (Voulgaris et al., 2000:127). Financial ratios have traditionally been, and continue to be, an important tool in evaluating the financial performance and position of the firm and helping managers with decision-making. Large amounts of financial information can be reduced to a few financial ratios that can indicate problem areas in an organisation. Managers of SMEs tend to fail at this task due to a lack of technical expertise and relevant knowledge (Kamyabi \& Devi, 2012:61).

The Balanced Scorecard (BSC) is a modern performance measurement tool with a strategic focus, consisting of a comprehensive set of performance measures across four balanced perspectives, namely the financial, customers, internal business processes and learning and growth perspectives (Kaplan \& Norton, 1996:2). A lack of knowledge and skills has been identified as one of the most prominent reasons why SMEs do not implement the Balanced Scorecard. Most SME managers are not aware of the Balanced Scorecard technique, and therefore do not use it (Rompho, 2011:39). 


\section{PROBLEM STATEMENT}

There is a clear need for more effective performance management in SMEs (Ates, Garengo, Cocca \& Bititci, 2013:46). This need is preceded by the need to facilitate the adoption of more formal and advanced management structures in SMEs to manage performance more effectively (Cagliano, Blackmon \& Voss, 2001:480).

Accountants in South Africa provide not only accounting services to businesses, but also managerial and advisory services. Accountants have the knowledge and skills to help managers of SMEs to achieve their business objectives (Kamyabi \& Devi, 2012:61). The question arises as to whether South African SME managers use performance measurement tools. Are they assisted by their accountants in using performance measurement tools? Can accountants help South African SME managers to use traditional financial ratios, or even the more modern and strategic Balanced Scorecard, to improve their business management and ultimately their business success?

Extensive research has been done on the prediction of small business failure through financial ratio models. These studies focus on the view of credit providers and not on performance management for business managers (Thomas \& Evanson, 1987:555; Voulgaris et al., 2000:127). Recent literature on financial ratios as a management tool in SMEs, however, is not as freely available. The Balanced Scorecard as applied in SMEs is also not as widely researched as the application of the Balanced Scorecard in larger firms, especially in South Africa.

The focus of this study is to determine whether accountants assist SME managers in South Africa in using performance measurement tools. Two performance measurement tools have been identified for this study: financial ratios as a traditional (older) tool and the Balanced Scorecard as a modern (newer) tool. The study will also seek to determine whether accountants think the use of these performance measurement tools can assist SME managers in improving management of their business and ultimately address the success and survival of their business.

The remainder of the article is structured as follows: in Section 3 the research objectives will be formulated. Section 4 will review relevant literature on financial ratios in SMEs and the Balanced Scorecard in SMEs as well as SME managers' lack of knowledge, skills or experience and the advisory services available to SMEs. The research design and methods are explained in Section 5, followed by the results and discussion thereof. Lastly Section 6 provides the conclusions on the study and recommendations that arise from it.

\section{RESEARCH OBJECTIVES}

In order to determine whether accountants assist SME managers in South Africa in using performance measurement tools, the following objectives must be achieved:

- Determine whether accountants calculate financial ratios for SME managers to use in managing their businesses,

- Identify which financial ratios accountants calculate for SME managers to use (if any),

- Determine whether accountants provide advice to SME managers on the use of financial ratios in managing their businesses,

- Determine if accountants regard the use of financial ratios as beneficial to SMEs, 
- Determine whether accountants develop the Balanced Scorecard for SME managers to use in managing their businesses,

- Determine whether accountants provide advice to SME managers on the use the Balanced Scorecard in managing their businesses, and

- Determine if accountants regard the use of the Balanced Scorecard as beneficial to SMEs.

This study contributes to the body of knowledge on performance management tools for small and medium businesses. Once current performance measurement practices of SMEs in South Africa are known, recommendations can be made as to how improvements to these practices can be effected. Through the application of improved performance management techniques, SMEs performance and overall success might improve, which in turn could help SMEs realise their potential as significant contributors to the South African economy.

This study is limited to the South African context, which will impact the findings of the study. The performance measurement tools used by SMEs, or their reasons and motivation for certain behaviour, are not studied in-depth. Future research can investigate further by performing detailed case studies and experimental application of the performance measurement tools in South African and international SMEs.

\section{LITERATURE REVIEW}

\subsection{SMEs and financial ratios}

Patrone and duBois (1981:35) state that small business owners and managers should gain the expertise and knowledge necessary to analyse their accounting and financial data, as it could mean the difference between success and failure. Financial ratio analysis is an analytical technique developed to analyse accounting and financial data. In an SME context, it provides the SME manager with an indication of where the business has been, where it is at now and where it is going.

Research on financial ratios and SMEs focuses more on financial ratios' ability to predict failure, and not on managerial use (Thomas \& Evanson, 1987:555; Voulgaris et al., 2000:127). Several models have been developed to help lenders and credit providers predict which small firms will survive and be able to repay their debt. These models use sophisticated statistical calculations and are not user-friendly to non-specialist decision-makers like the SME managers.

Mewse (2011:15) encourages business owners to monitor their business's performance continuously so that problems can be addressed as they arise. He proposes the use of a number of key ratios to help managers identify and rectify problems before the business enters a decline. Managers should keep an eye on expenses versus income, cash flow and working capital ratios.

Patrone and duBois (1981:35) warn that financial ratios should not be thought of as the answer to all of management's information needs. The next section describes the application of the Balanced Scorecard in SMEs, a tool that will provide SME managers with a more extensive array of information. 


\subsection{SMEs and the balanced scorecard}

The Balanced Scorecard is a framework consisting of a comprehensive set of performance measures. This performance measurement tool retains a strong focus on financial achievements, but supplements traditional financial measures with three additional perspectives. The organisation's performance is thus measured across four balanced perspectives, namely financial, customers, internal business processes and learning and growth perspectives. This strategic measurement and management tool is derived from and aligned to the firm's strategy and mission (Kaplan \& Norton, 1996:2).

Literature on the use and limitations of the Balanced Scorecard as applied in SMEs is hard to find. Since the development of the Balanced Scorecard in 1992, many large companies have successfully implemented this management tool. This cannot be said for SMEs, even though it is believed that it would be as beneficial to them as to large firms (Rompho, 2011:39).

Gumbus and Lussier (2006:410) state that if a SME does not measure its financial, customer, process and learning and growth aspects, the SME's manager and other stakeholders cannot know how well the SME is performing. In addition, they argue that if the SME wants to manage these aspects of the business, they have to be measured. The Balanced Scorecard can help SMEs by tracking performance. The Balanced Scorecard will also help by providing a clear focus on the firm's goals and promoting growth.

The few research studies performed on the application of the Balanced Scorecard in SMEs revealed conflicting results. Gumbus and Lussier (2006:410) found that the Balanced Scorecard helped SMEs to set strategies and align operations to achieve breakthrough results. They concluded that the Balanced Scorecard stimulated thinking about relevant measures and critical success factors to ensure continuous improvement. For this to be successful, the implementation should be a team-based and iterative process.

Research by Hanif and Manarvi (2010:577), on the other hand, indicated that the results achieved and the benefits perceived after the implementation of the Balanced Scorecard were not considered useful to SMEs. This research did, however, support the argument that knowledge of the tool will benefit SMEs. Non-financial measurements would also be considered as important, and the focus on a pure financial approach would evolve over time into a more holistic approach on performance measurement.

Rompho (2011:39) found that the SMEs under investigation failed to implement the Balanced Scorecard due to frequent strategy changes. In an environment where rapid response to changes in the market is necessary for survival, SMEs struggled to use the Balanced Scorecard. The lack of formal processes, a short-term orientation, limited human and capital resources and the lack of knowledge and skills are all too familiar reasons in explaining why SMEs fail in general business management. These same obstacles that SME managers face in the general management of their business also apply to the use of this modern performance measurement tool.

A lack of knowledge and skills has been identified as one of the most prominent reasons why SMEs do not implement the Balanced Scorecard. Most SME managers are not aware of the Balanced Scorecard technique, and therefore do not use it (Rompho, 2011:39). Machado (2013:142) found that even management accounting professionals who work in SMEs are unaware of this performance management tool. Machado (2013:142) suggests that even if the SMEs do not implement the Balanced Scorecard, knowledge of the tool will be beneficial to the 
businesses. The lack of knowledge and skill as a constraining factor, along with a suggestion as to how to overcome this obstacle, is discussed in the following sections.

\subsection{Lack of knowledge and skills}

Abor and Quartey (2010:225) found that one of the factors that constrains the development of SMEs is the lack of managerial skills and training of those individuals managing SMEs. SMEs tend to fail due to insufficient managerial knowledge and technical expertise (Kamyabi \& Devi, 2012:61). The knowledge and technical expertise necessary to manage a business successfully includes knowledge of a wide range of issues like product design, marketing, accounting and financial management (Robson \& Bennett, 2000:201).

Most SME owners rely on their accountants to prepare their financial statements (Sian \& Roberts, 2009: 289). The objective of financial statements is to provide the primary users with useful information. In the case of SMEs, the primary users of the financial statements are the South African Revenue Services (SARS), banks and most importantly the owners (Van Wyk \& Rossouw, 2009:99). Often the owners of SMEs are confused by the complexity and magnitude of information, due to a lack of training in accounting and business management (Sian \& Roberts, 2009: 289, 301).

South Africa has unique financial literacy challenges due to the differences in cultural backgrounds, emigration of skilled workers, and transformation. In order to overcome poverty and unemployment, South Africa needs individuals who are financially literate and can participate fully in the economy. Almost every decision a business manager makes has a financial impact, and will only be beneficial if this decision-maker has the knowledge and skills to make sound financial choices (Shuttleworth, 2009:71,105).

Where SME managers lack knowledge, skills or experience, they can seek advice from various sources. The advisory services available to SMEs are explained in the next section.

\subsection{Advisory services to SMEs}

Governments around the globe have introduced a variety of policies and frameworks to assist new firms and offer support to aid their survival. In addition to government advisory services, SMEs can also consult specialists and business associations and seek advice from social contacts and relatives. Lawyers, accountants, banks, suppliers and customers can also be used as sources of advice (Robson \& Bennett, 2000:193).

Just as there are several sources of advice, there are various types of advice. SMEs can seek advice on marketing, advertising, public relations, product design, computer services, business strategy, staff recruitment, financial management, taxation and legal services. The fields of advice that have a significant impact on turnover growth of SMEs are business strategy, staff recruitment, taxation and financial management (Robson \& Bennett, 2000:201; Berry, Sweeting \& Goto, 2006:44).

In the context of performance measurement, it is important to note that business strategy forms the core of the Balanced Scorecard (Kaplan \& Norton, 1996:2). The fields relating to staff and financial management are addressed by the learning and growth and the financial perspectives of the Balanced Scorecard respectively. This may indicate that advice to SMEs on the implementation of a Balanced Scorecard will also improve the SMEs performance. 
Robson and Bennett (2000:201) found that accountants are the most used source of advice. This finding is supported by research undertaken by Berry et al. (2006:38). The latter found, however, that no significant relationship between the advice from accountants to the SME managers and the SMEs performance exists. Robson and Bennett (2000:201) state that this is the case due to the nature of the advice given by accountants. SMEs only sought advice from accountants related to auditing, and not advice on business strategy, taxation and business or financial management. Berry et al. (2006:44) also concluded that accountants mostly provided advice related to statutory work, with little focus on business and financial management.

Kamyabi and Devi (2012:69) found that accountants' advisory services are positively associated with the performance of SMEs in developing countries. In contrast to findings in developed countries (Robson \& Bennett, 2000:201; Berry et al., 2006:44), they noted that any advice from accountants directly improved the performance of SMEs in developing countries. They speculate that this is caused by the fact that entrepreneurs in developed countries are more financially literate than those in developing countries. It is also more difficult to recruit and retain skilled and qualified employees in developing countries. Their findings indicate that the advice of accountants play a mediating role between the SME managers' knowledge, the complexity of management decisions, the intensity of competition and SMEs' performance.

Accountants are in an unparalleled position to assist and advise managers of SMEs to overcome the skills and knowledge gap in managing their own business (Kamyabi \& Devi, 2012:69). This may also be true in the use of performance measurement tools. It is clear from the discussion above that accountants are a trusted source of advice to SMEs, and that SMEs need assistance in utilising performance measurement tools.

\section{RESEARCH DESIGN AND METHODOLOGY}

Persons registered as Business Accountants in Practice (BAP(SA)) with the South African Institute of Business Accountants (SAIBA) served as the sources of data (throughout referred to as accountants). Business accountants are accountants who provide accounting and assurance, taxation and management consultancy services, with a greater emphasis on management accounting than their counterparts called professional accountants.

Accountants are an invaluable source of data, as they work with SMEs on a daily basis. The accountants were chosen as the source of data, as it is easier to reach a large sample of accountants than SMEs, as they can be contacted through one central point: in this case the professional body SAIBA. The electronic survey was sent to all South African accountants registered with SAIBA during the 2013 calendar year (1495 members). The survey was only sent to SAIBA members, as other accounting professional bodies did not wish to participate in the study.

The accountants were requested to indicate if they render accounting and/or advisory services to SMEs. Only the responses of the accountants that provide accounting and/or advisory services to SMEs have been used in an attempt to reach the specified objectives of the study. A total of 174 responses were received, of which 150 were complete (response rate $=10.03 \%$ ). Of the 150 usable responses received, 140 respondents indicated that they provide accounting and/or advisory services to SMEs.

The focus area of the study is SMEs in South Africa. A SME is defined in this study as a small private business with fewer than 50 full-time employees as defined by the National Small 
Business Amendment Act No. 26 of 2003. The SMEs themselves will not be studied in detail, and no information on a specific SME was requested to be divulged on the questionnaire.

A self-administered questionnaire was used to collect data. Only closed questions, where respondents answered on a five-point Likert scale, were included in the questionnaire. The Likert scale ranges from "strongly disagree" to "strongly agree". The questions are posed as statements, and respondents were requested to indicate the extent to which they agree or disagree with the statement. The questionnaire is electronically based, using the Qualtrics Online Survey Software programme. The questionnaire and cover letter was sent to SAIBA, which in turn sent an email containing a link to the internet-based questionnaire to all its members requesting them to complete the survey.

The questionnaire was structured in three sections. In the first section, data is collected on the work experience, training and education of the accountants. The accountants were asked to indicate whether they are familiar with the two performance measurement tools (financial ratios and the Balanced Scorecard), and when they last updated their knowledge on these topics. The second section focused on collecting data on the usage of financial ratios by SMEs, and whether the accountants deem financial ratios as important in managing a small business. This section also focused on the advisory services relating to financial ratios that accountants provide to SMEs. The last section asked questions on the use of the Balanced Scorecard as a performance measurement tool by SMEs. This section also included an opinion poll on advisory services and the benefit of the Balanced Scorecard to SMEs.

To do an in-depth study on the use of performance measurement tools by SMEs, it would be logical to study the SMEs itself. By conducting interviews with the managers, observing the dayto-day practices and scrutinising the businesses' documents, the researcher would get a clear indication on what SMEs use as performance measurement tools and how they use these. It would, however, take an inordinate amount of time to collect this data from only a few SMEs. For the purpose of this study, the chosen method was deemed most appropriate.

This study attempts to create a starting point for further research on performance measurement and SMEs. An overall view in the current performance measurement practices of SMEs in South Africa was created. A questionnaire distributed among all the accountants is therefore deemed to be a good technique to gather the required basic data from a large group of respondents. Most SMEs rely on their accountants to prepare their financial statements (Sian \& Roberts, 2009: 289). To apply for financing at a bank and to comply with Income Tax and Value Added Tax legislation, SMEs need accurate accounting records and financial statements. Accountants have to work in close relation to the SME managers every day and are therefore a valuable and viable source of data.

\section{RESULTS AND DISCUSSION}

It is important for all professionals to continue their development and stay up to date with current practices and developments. Accounting practitioners can update their knowledge through seminars and training courses or by reading academic journals and articles published by professional bodies like SAIBA. TABLE I below provides a summary of the respondents' continued professional development on financial ratios and the Balanced Scorecard. 
TABLE 1: Last time knowledge on Financial Ratios (FR) and BSC was updated

\begin{tabular}{|c|c|c|c|c|}
\hline Response & $\begin{array}{l}\text { FR Knowledge } \\
\text { update }\end{array}$ & Heard about BSC & $\begin{array}{c}\text { BSC Knowledge } \\
\text { update }\end{array}$ & $\begin{array}{l}\text { Formal } \\
\text { training in } \\
\text { BSC }\end{array}$ \\
\hline Never & $4.29 \%$ & $22.86 \%$ & $51.43 \%$ & yes $-20.71 \%$ \\
\hline $\begin{array}{l}\text { Less than } 1 \text { year } \\
\text { ago }\end{array}$ & $60.71 \%$ & $23.57 \%$ & $28.57 \%$ & No $-79.29 \%$ \\
\hline $1-2$ years ago & $20.71 \%$ & $20.00 \%$ & $9.29 \%$ & \\
\hline $2-5$ years ago & $10.71 \%$ & $13.57 \%$ & $9.29 \%$ & \\
\hline $5-10$ years ago & $1.43 \%$ & $12.14 \%$ & $1.43 \%$ & \\
\hline $\begin{array}{l}\text { More than } 10 \text { years } \\
\text { ago }\end{array}$ & $2.14 \%$ & $7.86 \%$ & $0.00 \%$ & \\
\hline Total & $100.00 \%$ & $100.00 \%$ & $100.00 \%$ & \\
\hline
\end{tabular}

Source: Authors' calculations

The respondents were requested to indicate when they last updated their knowledge on financial ratios. The majority of the respondents $(60.71 \%)$ updated their knowledge on this performance measurement tool in the last year, while only $4.29 \%$ indicated that they have not stayed up to date with current developments.

It is clear from TABLE 1 that the majority of the respondents have heard about the Balanced Scorecard, but less than two years ago. This may be due to the fact that almost $80 \%$ of the respondents have not received formal training on the Balanced Scorecard (i.e. as part of their degree/diploma).

The respondents were also required to indicate when they last updated their knowledge on the Balanced Scorecard. $51.43 \%$ of the respondents have never updated their knowledge on the Balanced Scorecard. This can be expected, as $22.86 \%$ of the respondents have never heard of the Balanced Scorecard. Of the respondents that have updated their knowledge (48.58\%), more than half (28.57\%) have done so in the past year.

\subsection{Univariate analysis}

In the second and third sections of the questionnaire, the respondents were required to indicate their level of agreement on several statements concerning the two performance measurement tools respectively. A five-point Likert scale was used, ranging from "l - Strongly Disagree" to "5 - Strongly Agree".

\subsubsection{Financial ratios}

TABLE 2 provides the frequencies of responses per statement relating to financial ratios. Statements 1.6 and 1.7 from TABLE 2 are concerned with whether accountants calculate financial ratios for SMEs. It is clear from the mode (3.73) and the mean (3.8) that most accountants do calculate financial ratios for SMEs, and explain the results to the SME managers. 
About $15 \%$ of the respondents, however, indicated that they do not calculate financial ratios, and $13.57 \%$ were undecided.

Statements 1.3 (mean 2.25) and 1.4 (mean 4.41) indicate that the respondents strongly feel that SME managers need advice on financial ratios, as they do not have knowledge on the topic. Accountants have the ability to provide this advice to SME managers (statement 1.5, mean 4.26). Despite this, statement 1.8 (mean 3.72) indicates that accountants do not provide as much advice on financial ratios to SME managers as they believe is necessary.

TABLE 2: Summary of responses on Financial Ratios statements

\begin{tabular}{|c|c|c|c|c|c|c|c|c|}
\hline No & Statement & $\begin{array}{l}\text { Strongly } \\
\text { Disagree }\end{array}$ & Disagree & $\begin{array}{l}\text { Undecided } \\
\text { (Neutral) }\end{array}$ & Agree & $\begin{array}{c}\text { Strongly } \\
\text { Agree }\end{array}$ & $n$ & Mean \\
\hline 1.1 & $\begin{array}{l}\text { The use of } \\
\text { financial ratios is } \\
\text { important in } \\
\text { managing a SME }\end{array}$ & $\begin{array}{c}1 \\
0.71 \%\end{array}$ & $\begin{array}{c}4 \\
2.86 \%\end{array}$ & $\begin{array}{c}18 \\
12.86 \%\end{array}$ & $\begin{array}{c}60 \\
42.86 \%\end{array}$ & $\begin{array}{c}57 \\
40.71 \%\end{array}$ & $\begin{array}{c}140 \\
100 \%\end{array}$ & 4.20 \\
\hline 1.2 & $\begin{array}{l}\text { The use of } \\
\text { financial ratios } \\
\text { by SMEs can help } \\
\text { to improve their } \\
\text { performance }\end{array}$ & $\begin{array}{c}1 \\
0.71 \%\end{array}$ & $\begin{array}{c}1 \\
0.71 \%\end{array}$ & $\begin{array}{c}14 \\
10.00 \%\end{array}$ & $\begin{array}{c}69 \\
49.29 \%\end{array}$ & $\begin{array}{c}55 \\
39.29 \%\end{array}$ & $\begin{array}{c}140 \\
100 \%\end{array}$ & 4.26 \\
\hline 1.3 & $\begin{array}{l}\text { SME managers } \\
\text { have knowledge } \\
\text { on financial } \\
\text { ratios }\end{array}$ & $\begin{array}{c}36 \\
25.71 \%\end{array}$ & $\begin{array}{c}61 \\
43.57 \%\end{array}$ & $\begin{array}{c}22 \\
15.71 \%\end{array}$ & $\begin{array}{c}14 \\
10.00 \%\end{array}$ & $\begin{array}{c}7 \\
5.00 \%\end{array}$ & $\begin{array}{c}140 \\
100 \%\end{array}$ & 2.25 \\
\hline 1.4 & $\begin{array}{l}\text { SME managers } \\
\text { need advice on } \\
\text { financial ratios in } \\
\text { order to be able } \\
\text { to use it }\end{array}$ & $\begin{array}{c}2 \\
1.43 \%\end{array}$ & $\begin{array}{c}1 \\
0.71 \%\end{array}$ & $\begin{array}{c}7 \\
5.00 \%\end{array}$ & $\begin{array}{c}58 \\
41.43 \%\end{array}$ & $\begin{array}{c}72 \\
51.43 \%\end{array}$ & $\begin{array}{c}140 \\
100 \%\end{array}$ & 4.41 \\
\hline 1.5 & $\begin{array}{l}\text { Accountants have } \\
\text { the ability to } \\
\text { provide SME } \\
\text { managers with } \\
\text { advice on } \\
\text { financial ratios }\end{array}$ & $\begin{array}{c}0 \\
0.00 \%\end{array}$ & $\begin{array}{c}5 \\
3.57 \%\end{array}$ & $\begin{array}{c}8 \\
5.71 \%\end{array}$ & $\begin{array}{c}72 \\
51.43 \%\end{array}$ & $\begin{array}{c}55 \\
39.29 \%\end{array}$ & $\begin{array}{c}140 \\
100 \%\end{array}$ & 4.26 \\
\hline 1.6 & $\begin{array}{l}\text { I provide } \\
\text { calculated } \\
\text { financial ratios } \\
\text { to SME managers }\end{array}$ & $\begin{array}{c}3 \\
2.14 \%\end{array}$ & $\begin{array}{c}20 \\
14.29 \%\end{array}$ & $\begin{array}{c}19 \\
13.57 \%\end{array}$ & $\begin{array}{c}68 \\
48.57 \%\end{array}$ & $\begin{array}{c}30 \\
21.43 \%\end{array}$ & $\begin{array}{c}140 \\
100 \%\end{array}$ & 3.73 \\
\hline 1.7 & $\begin{array}{l}\text { I explain the } \\
\text { results of the } \\
\text { financial ratios } \\
\text { to the SME } \\
\text { managers }\end{array}$ & $\begin{array}{c}3 \\
2.14 \%\end{array}$ & $\begin{array}{c}16 \\
11.43 \%\end{array}$ & $\begin{array}{c}19 \\
13.57 \%\end{array}$ & $\begin{array}{c}70 \\
50.00 \%\end{array}$ & $\begin{array}{c}32 \\
22.86 \%\end{array}$ & $\begin{array}{c}140 \\
100 \%\end{array}$ & 3.80 \\
\hline
\end{tabular}




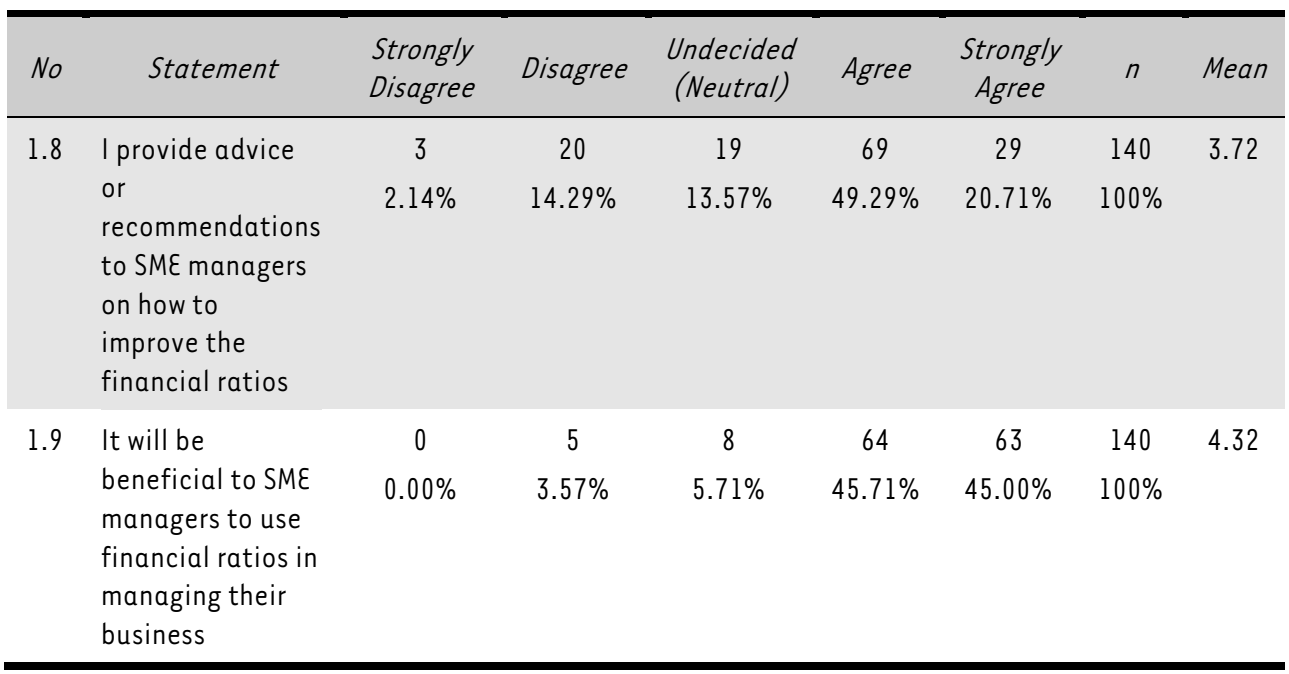

Source: Authors' calculations

Three statements, as shown in TABLE 2, were given to determine whether the accountants regard the use of financial ratios as beneficial to SMEs. Statements 1.1 (mean 4.2), 1.2 (mean 4.26) and 1.9 (mean 4.32) indicate that the respondents strongly agree that the use of financial ratios is important, it can help to improve the SMEs performance and it will be beneficial to SME managers to use these performance measures in managing their business.

The second part of the financial ratios section of the questionnaire was aimed at determining which financial ratios accountants calculate for SME managers to use (if any). The respondents were provided with a list of financial ratios as identified in relevant literature. The respondents could also name additional financial ratios they calculate if these ratios were not provided in the list. TABLE 3 shows a summary of the results of financial ratios calculated by accountants for SMEs.

\section{TABLE 3: Summary of Financial Ratios calculated by accountants for SMEs}

\begin{tabular}{|c|c|c|c|c|c|c|c|c|}
\hline No & Financial Ratio & $\begin{array}{l}\text { Strongly } \\
\text { Disagree }\end{array}$ & Disagree & $\begin{array}{l}\text { Undecided } \\
\text { (Neutral) }\end{array}$ & Agree & $\begin{array}{c}\text { Strongly } \\
\text { Agree }\end{array}$ & $n$ & Mean \\
\hline \multirow[t]{2}{*}{2.1} & Current Ratio & 4 & 10 & 9 & 63 & 54 & 140 & 4.09 \\
\hline & $\begin{array}{l}\text { (Current Assets / } \\
\text { Current } \\
\text { Liabilities) }\end{array}$ & $2.86 \%$ & $7.14 \%$ & $6.43 \%$ & $45.00 \%$ & $38.57 \%$ & $100 \%$ & \\
\hline \multirow[t]{2}{*}{2.2} & Quick Ratio & 4 & 11 & 16 & 60 & 48 & 139 & 3.99 \\
\hline & $\begin{array}{l}\text { (Current Assets - } \\
\text { Inventory / } \\
\text { Current } \\
\text { Liabilities) }\end{array}$ & $2.88 \%$ & $7.91 \%$ & $11.51 \%$ & $43.17 \%$ & $34.53 \%$ & $100 \%$ & \\
\hline \multirow[t]{2}{*}{2.3} & Net Working & 3 & 10 & 14 & 62 & 49 & 138 & 4.04 \\
\hline & $\begin{array}{l}\text { Capital } \\
\text { (Current Assets - } \\
\text { Current }\end{array}$ & $2.17 \%$ & $7.25 \%$ & $10.14 \%$ & $44.93 \%$ & $35.51 \%$ & $100 \%$ & \\
\hline
\end{tabular}




\begin{tabular}{|c|c|c|c|c|c|c|c|c|}
\hline No & Financial Ratio & $\begin{array}{l}\text { Strongly } \\
\text { Disagree }\end{array}$ & Disagree & $\begin{array}{c}\text { Undecided } \\
\text { (Neutral) }\end{array}$ & Agree & $\begin{array}{c}\text { Strongly } \\
\text { Agree }\end{array}$ & $n$ & Mean \\
\hline & Liabilities) & & & & & & & \\
\hline \multirow[t]{2}{*}{2.4} & Inventory & 3 & 13 & 24 & 55 & 43 & 138 & 3.88 \\
\hline & $\begin{array}{l}\text { Turnover } \\
\text { (Cost of Sales / } \\
\text { Inventory) }\end{array}$ & $2.17 \%$ & $9.42 \%$ & $17.39 \%$ & $39.86 \%$ & $31.16 \%$ & $100 \%$ & \\
\hline \multirow[t]{2}{*}{2.5} & Debtor's & 7 & 15 & 19 & 56 & 41 & 138 & 3.79 \\
\hline & $\begin{array}{l}\text { Collection Period } \\
\text { (Debtors/Average } \\
\text { sales per day) }\end{array}$ & $5.07 \%$ & $10.87 \%$ & $13.77 \%$ & $40.58 \%$ & $29.71 \%$ & $100 \%$ & \\
\hline \multirow[t]{2}{*}{2.6} & Creditor's & 7 & 17 & 23 & 54 & 37 & 138 & 3.70 \\
\hline & $\begin{array}{l}\text { Payment Period } \\
\text { (Creditors / } \\
\text { Average credit } \\
\text { purchases per } \\
\text { day) }\end{array}$ & $5.07 \%$ & $12.32 \%$ & $16.67 \%$ & $39.13 \%$ & $26.81 \%$ & $100 \%$ & \\
\hline \multirow[t]{2}{*}{2.7} & Fixed Asset & 5 & 23 & 41 & 41 & 26 & 136 & 3.44 \\
\hline & $\begin{array}{l}\text { Turnover } \\
\text { (Sales/Net Fixed } \\
\text { Assets) }\end{array}$ & $3.68 \%$ & $16.91 \%$ & $30.15 \%$ & $30.15 \%$ & $19.12 \%$ & $100 \%$ & \\
\hline \multirow[t]{2}{*}{2.8} & Total Asset & 5 & 24 & 32 & 47 & 29 & 137 & 3.52 \\
\hline & $\begin{array}{l}\text { Turnover } \\
\text { (Sales/Total } \\
\text { Assets) }\end{array}$ & $3.65 \%$ & $17.52 \%$ & $23.36 \%$ & $34.31 \%$ & $21.17 \%$ & $100 \%$ & \\
\hline \multirow[t]{2}{*}{2.9} & Debt Ratio & 4 & 13 & 17 & 60 & 43 & 137 & 3.91 \\
\hline & $\begin{array}{l}\text { (Total Debt / } \\
\text { Total Assets) }\end{array}$ & $2.92 \%$ & $9.49 \%$ & $12.41 \%$ & $43.80 \%$ & $31.39 \%$ & $100 \%$ & \\
\hline \multirow[t]{2}{*}{2.10} & Debt to Equity & 4 & 18 & 24 & 53 & 36 & 135 & 3.73 \\
\hline & $\begin{array}{l}\text { Ratio } \\
\text { (Long term debt / } \\
\text { Equity) }\end{array}$ & $2.96 \%$ & $13.33 \%$ & $17.78 \%$ & $39.26 \%$ & $26.67 \%$ & $100 \%$ & \\
\hline \multirow[t]{2}{*}{2.11} & Interest Cover & 6 & 17 & 38 & 45 & 28 & 134 & 3.54 \\
\hline & $\begin{array}{l}\text { Ratio } \\
\text { (Profit before } \\
\text { Interest \& Tax / } \\
\text { Interest) }\end{array}$ & $4.48 \%$ & $12.69 \%$ & $28.36 \%$ & $33.58 \%$ & $20.90 \%$ & $100 \%$ & \\
\hline \multirow[t]{2}{*}{2.12} & Net profit margin & 2 & 8 & 10 & 59 & 59 & 138 & 4.20 \\
\hline & $\begin{array}{l}\text { (Net profit / } \\
\text { Sales) }\end{array}$ & $1.45 \%$ & $5.80 \%$ & $7.25 \%$ & $42.75 \%$ & $42.75 \%$ & $100 \%$ & \\
\hline \multirow[t]{2}{*}{2.13} & Gross profit & 1 & 5 & 6 & 60 & 65 & 137 & 4.34 \\
\hline & $\begin{array}{l}\text { margin } \\
\text { (Gross profit / } \\
\text { Sales) }\end{array}$ & $0.73 \%$ & $3.65 \%$ & $4.38 \%$ & $43.80 \%$ & $47.45 \%$ & $100 \%$ & \\
\hline
\end{tabular}




\begin{tabular}{|c|c|c|c|c|c|c|c|c|}
\hline No & Financial Ratio & $\begin{array}{l}\text { Strongly } \\
\text { Disagree }\end{array}$ & Disagree & $\begin{array}{l}\text { Undecided } \\
\text { (Neutral) }\end{array}$ & Agree & $\begin{array}{l}\text { Strongly } \\
\text { Agree }\end{array}$ & $n$ & Mean \\
\hline 2.14 & $\begin{array}{l}\text { Net operating } \\
\text { profit margin } \\
\text { (Profit before } \\
\text { Interest \& } \\
\text { Tax/Sales) }\end{array}$ & $\begin{array}{c}4 \\
2.92 \%\end{array}$ & $\begin{array}{c}8 \\
5.84 \%\end{array}$ & $\begin{array}{c}23 \\
16.79 \%\end{array}$ & $\begin{array}{c}59 \\
43.07 \%\end{array}$ & $\begin{array}{c}43 \\
31.39 \%\end{array}$ & $\begin{array}{c}137 \\
100 \%\end{array}$ & 3.94 \\
\hline 2.15 & $\begin{array}{l}\text { Return on Assets } \\
\text { (Net Profit / } \\
\text { Assets) }\end{array}$ & $\begin{array}{c}4 \\
2.94 \%\end{array}$ & $\begin{array}{c}18 \\
13.24 \%\end{array}$ & $\begin{array}{c}32 \\
23.53 \%\end{array}$ & $\begin{array}{c}52 \\
38.24 \%\end{array}$ & $\begin{array}{c}30 \\
22.06 \%\end{array}$ & $\begin{array}{c}136 \\
100 \%\end{array}$ & 3.63 \\
\hline 2.16 & $\begin{array}{l}\text { Return on Equity } \\
\text { (Net Profit / } \\
\text { Equity) }\end{array}$ & $\begin{array}{c}4 \\
2.96 \%\end{array}$ & $\begin{array}{c}18 \\
13.33 \%\end{array}$ & $\begin{array}{c}31 \\
22.96 \%\end{array}$ & $\begin{array}{c}53 \\
39.26 \%\end{array}$ & $\begin{array}{c}29 \\
21.48 \%\end{array}$ & $\begin{array}{c}135 \\
100 \%\end{array}$ & 3.63 \\
\hline 2.17 & $\begin{array}{l}\text { Return on Capital } \\
\text { employed } \\
\text { (Net Profit/Equity } \\
+ \text { Debt) }\end{array}$ & $\begin{array}{c}4 \\
2.96 \%\end{array}$ & $\begin{array}{c}21 \\
15.56 \%\end{array}$ & $\begin{array}{c}40 \\
29.63 \%\end{array}$ & $\begin{array}{c}42 \\
31.11 \%\end{array}$ & $\begin{array}{c}28 \\
20.74 \%\end{array}$ & $\begin{array}{c}135 \\
100 \%\end{array}$ & 3.51 \\
\hline 2.18 & $\begin{array}{l}\text { Change in Net } \\
\text { Profit } \\
\text { (Net Profit for } \\
\text { current and } \\
\text { previous year) }\end{array}$ & $\begin{array}{c}3 \\
2.21 \%\end{array}$ & $\begin{array}{c}10 \\
7.35 \%\end{array}$ & $\begin{array}{c}20 \\
14.71 \%\end{array}$ & $\begin{array}{c}57 \\
41.91 \%\end{array}$ & $\begin{array}{c}46 \\
33.82 \%\end{array}$ & $\begin{array}{c}136 \\
100 \%\end{array}$ & 3.98 \\
\hline 2.19 & $\begin{array}{l}\text { Change in Gross } \\
\text { Profit } \\
\text { (Gross profit for } \\
\text { current and } \\
\text { previous year) }\end{array}$ & $\begin{array}{c}2 \\
1.48 \%\end{array}$ & $\begin{array}{c}9 \\
6.67 \%\end{array}$ & $\begin{array}{c}20 \\
14.81 \%\end{array}$ & $\begin{array}{c}56 \\
41.48 \%\end{array}$ & $\begin{array}{c}48 \\
35.56 \%\end{array}$ & $\begin{array}{c}135 \\
100 \%\end{array}$ & 4.03 \\
\hline 2.20 & $\begin{array}{l}\text { Cash flow to sales } \\
\text { (Cash flow / } \\
\text { sales) }\end{array}$ & $\begin{array}{c}4 \\
2.96 \%\end{array}$ & $\begin{array}{c}18 \\
13.33 \%\end{array}$ & $\begin{array}{c}27 \\
20.00 \%\end{array}$ & $\begin{array}{c}45 \\
33.33 \%\end{array}$ & $\begin{array}{c}41 \\
30.37 \%\end{array}$ & $\begin{array}{c}135 \\
100 \%\end{array}$ & 3.75 \\
\hline 2.21 & $\begin{array}{l}\text { Cash flow to total } \\
\text { assets } \\
\text { (Cash flow / Total } \\
\text { Assets) }\end{array}$ & $\begin{array}{c}4 \\
2.96 \%\end{array}$ & $\begin{array}{c}22 \\
16.30 \%\end{array}$ & $\begin{array}{c}39 \\
28.89 \%\end{array}$ & $\begin{array}{c}37 \\
27.41 \%\end{array}$ & $\begin{array}{c}33 \\
24.44 \%\end{array}$ & $\begin{array}{c}135 \\
100 \%\end{array}$ & 3.54 \\
\hline 2.22 & $\begin{array}{l}\text { Cash flow to total } \\
\text { debt } \\
\text { (Cash flow / Total } \\
\text { Debt) }\end{array}$ & $\begin{array}{c}5 \\
3.70 \%\end{array}$ & $\begin{array}{c}22 \\
16.30 \%\end{array}$ & $\begin{array}{c}39 \\
28.89 \%\end{array}$ & $\begin{array}{c}38 \\
28.15 \%\end{array}$ & $\begin{array}{c}31 \\
22.96 \%\end{array}$ & $\begin{array}{c}135 \\
100 \%\end{array}$ & 3.50 \\
\hline
\end{tabular}

Source: Authors' calculations

From TABLE 3 it is clear that most accountants calculate many of the given financial ratios. Only the cash flow to total assets (no. 21) and cash flow to total debt (no. 22) ratios have a mode of less than 4 . All the financial ratios have a mean above 3 , indicating that accountants more often than not calculate financial ratios for SMEs, using a broad spectrum of ratios. 
The five most calculated financial ratios are the current ratio, net working capital, net profit margin, gross profit margin and change in gross profit. These ratios are basic profitability and liquidity ratios. Three more ratios (quick ratio, net operating profit margin and change in net profit) have means between 3.9 and 4 , and also fall into the profitability and liquidity categories. The only ratio with a mean above 3.9 that considers long-term debt and fixed assets is the debt ratio. All of these ratios are relatively easy to calculate, as the components of the ratio can be taken directly from the financial statements.

The financial ratios with the lowest means are fixed asset turnover, total asset turnover, return on capital employed, cash flow to total debt, cash flow to total assets and the interest cover ratio. These ratios focus on assets and debt, and the relationship between assets or debt and turnover and cash flow. A possible explanation why the ratios relating to assets and fixed assets are considered less important might be because SMEs often do not own the large machinery and property used in line of business as they cannot afford it. Cash flow ratios, however, are very important, as without cash SMEs cannot survive. SMEs need to be aware of their ability to service their debt - not only the capital portion but also the associated interest (Banos-Caballero, Garcia-Teruel \& Martinez-Solano, 2010).

\subsubsection{Balanced Scorecard}

TABLE 4 provides a summary of the responses of the statement on the Balanced Scorecard. These statements were similarly formulated to the financial ratios statements; only the term "financial ratios" was changed to the term "Balanced Scorecard". Only responses from respondents who have heard of the Balanced Scorecard were included in this analysis $(n=108)$. Respondents who have never heard of the Balanced Scorecard would not be able to provide useful feedback on the topic.

TABLE 4: Summary of responses on the Balanced Scorecard statements

\begin{tabular}{|c|c|c|c|c|c|c|c|c|}
\hline No & Statement & $\begin{array}{l}\text { Strongly } \\
\text { Disagree }\end{array}$ & Disagree & $\begin{array}{l}\text { Undecided } \\
\text { (Neutral) }\end{array}$ & Agree & $\begin{array}{c}\text { Strongly } \\
\text { Agree }\end{array}$ & $n$ & Mean \\
\hline \multirow[t]{2}{*}{3.1} & The use of the & 0 & 7 & 31 & 39 & 31 & 108 & 3.87 \\
\hline & $\begin{array}{l}\text { Balanced } \\
\text { Scorecard is } \\
\text { important in } \\
\text { managing a SME }\end{array}$ & $0.00 \%$ & $6.48 \%$ & $28.70 \%$ & $36.11 \%$ & $28.70 \%$ & $100 \%$ & \\
\hline \multirow[t]{2}{*}{3.2} & The use of the & 0 & 6 & 20 & 55 & 27 & 108 & 3.95 \\
\hline & $\begin{array}{l}\text { Balanced } \\
\text { Scorecard by SMEs } \\
\text { can help to } \\
\text { improve their } \\
\text { performance }\end{array}$ & $0.00 \%$ & $5.56 \%$ & $18.52 \%$ & $50.93 \%$ & $25.00 \%$ & $100 \%$ & \\
\hline \multirow[t]{2}{*}{3.3} & SME managers & 17 & 44 & 21 & 17 & 9 & 108 & 2.60 \\
\hline & $\begin{array}{l}\text { have knowledge on } \\
\text { the Balanced } \\
\text { Scorecard }\end{array}$ & $15.74 \%$ & $40.74 \%$ & $19.44 \%$ & $15.74 \%$ & $8.33 \%$ & $100 \%$ & \\
\hline \multirow[t]{2}{*}{3.4} & SME managers & 1 & 4 & 15 & 52 & 36 & 108 & 4.09 \\
\hline & $\begin{array}{l}\text { need advice on the } \\
\text { Balanced }\end{array}$ & $0.93 \%$ & $3.70 \%$ & $13.89 \%$ & $48.15 \%$ & $33.33 \%$ & $100 \%$ & \\
\hline
\end{tabular}




\begin{tabular}{|c|c|c|c|c|c|c|c|c|}
\hline No & Statement & $\begin{array}{l}\text { Strongly } \\
\text { Disagree }\end{array}$ & Disagree & $\begin{array}{l}\text { Undecided } \\
\text { (Neutral) }\end{array}$ & Agree & $\begin{array}{l}\text { Strongly } \\
\text { Agree }\end{array}$ & $n$ & Mean \\
\hline & $\begin{array}{l}\text { Scorecard in order } \\
\text { to be able to use it }\end{array}$ & & & & & & & \\
\hline 3.5 & $\begin{array}{l}\text { Accountants have } \\
\text { the ability to } \\
\text { provide SME } \\
\text { managers with } \\
\text { advice on the } \\
\text { Balanced } \\
\text { Scorecard }\end{array}$ & $\begin{array}{c}0 \\
0.00 \%\end{array}$ & $\begin{array}{c}8 \\
7.41 \%\end{array}$ & $\begin{array}{c}24 \\
22.22 \%\end{array}$ & $\begin{array}{c}47 \\
43.52 \%\end{array}$ & $\begin{array}{c}29 \\
26.85 \%\end{array}$ & $\begin{array}{c}108 \\
100 \%\end{array}$ & 3.90 \\
\hline 3.6 & $\begin{array}{l}\text { I provide a } \\
\text { Balanced } \\
\text { Scorecard to SME } \\
\text { managers }\end{array}$ & $\begin{array}{c}9 \\
8.33 \%\end{array}$ & $\begin{array}{c}20 \\
18.52 \%\end{array}$ & $\begin{array}{c}41 \\
37.96 \%\end{array}$ & $\begin{array}{c}26 \\
24.07 \%\end{array}$ & $\begin{array}{c}12 \\
11.11 \%\end{array}$ & $\begin{array}{c}108 \\
100 \%\end{array}$ & 3.11 \\
\hline 3.7 & $\begin{array}{l}\text { I explain the } \\
\text { results of the } \\
\text { Balanced } \\
\text { Scorecard to the } \\
\text { SME managers }\end{array}$ & $\begin{array}{c}9 \\
8.33 \%\end{array}$ & $\begin{array}{c}19 \\
17.59 \%\end{array}$ & $\begin{array}{c}39 \\
36.11 \%\end{array}$ & $\begin{array}{c}28 \\
25.93 \%\end{array}$ & $\begin{array}{c}13 \\
12.04 \%\end{array}$ & $\begin{array}{c}108 \\
100 \%\end{array}$ & 3.16 \\
\hline 3.8 & $\begin{array}{l}\text { I provide advice or } \\
\text { recommendations } \\
\text { to SME managers } \\
\text { on how to improve } \\
\text { the Balanced } \\
\text { Scorecard results }\end{array}$ & $\begin{array}{c}8 \\
7.41 \%\end{array}$ & $\begin{array}{c}23 \\
21.30 \%\end{array}$ & $\begin{array}{c}35 \\
32.41 \%\end{array}$ & $\begin{array}{c}30 \\
27.78 \%\end{array}$ & $\begin{array}{c}12 \\
11.11 \%\end{array}$ & $\begin{array}{c}108 \\
100 \%\end{array}$ & 3.14 \\
\hline 3.9 & $\begin{array}{l}\text { It will be beneficial } \\
\text { to SME managers } \\
\text { to use the } \\
\text { Balanced } \\
\text { Scorecard in } \\
\text { managing their } \\
\text { business }\end{array}$ & $\begin{array}{c}0 \\
0.00 \%\end{array}$ & $\begin{array}{c}4 \\
3.70 \%\end{array}$ & $\begin{array}{c}22 \\
20.37 \%\end{array}$ & $\begin{array}{c}52 \\
48.15 \%\end{array}$ & $\begin{array}{c}30 \\
27.78 \%\end{array}$ & $\begin{array}{c}108 \\
100 \%\end{array}$ & 4.00 \\
\hline
\end{tabular}

Source: Authors' calculations

Statements 3.6 and 3.7 from TABLE 4 are concerned with whether accountants develop a Balanced Scorecard for SMEs. The "undecided (neutral)" option was chosen the most by the respondents. The mean for these statements, 3.11 and 3.16 respectively, also indicates that the respondents are undecided. A large portion of the respondents indicated that they do not provide a Balanced Scorecard to SME managers. These results could be expected, as $79.29 \%$ did not receive formal training relating to the Balanced Scorecard and $51.43 \%$ never updated their knowledge on this topic (Refer to TABLE 1).

Statements 3.3 (mean 2.6) and 3.4 (mean 4.09) indicate that the respondents feel that SME managers need advice on the Balanced Scorecard, as they do not have knowledge on the topic. It is interesting to note that the mean for statement 3.4 is the highest at above 4 . The respondents indicated with more certainty than in statements 3.6 and 3.7 (regarding their own knowledge) that SME managers do not have knowledge of this tool and therefore need advice in 
order to be able to use it. The accountants, however, do not provide this much-needed advice to SME managers, as is clear from statement 3.8. A possible reason for this is because the accountants themselves are not familiar with this performance measurement tool.

Three statements were given to determine whether the accountants regard the use of the Balanced Scorecard as beneficial to SMEs. Statements 3.1 (mean 3.87), 3.2 (mean 3.95) and 3.9 (mean 4) indicate that the respondents regard this performance measurement tool as important; it can help to improve the SMEs performance and it will be beneficial to SME managers to use it in managing their business. These results show that, although this performance measurement tool is not widely known or used, it is considered that this tool has the potential to improve SMEs' performance.

\subsection{Bivariate analysis}

A univariate analysis can provide insightful results, but only evaluates each variable in isolation. To determine whether or not relationships exist between the variables, one must perform a bivariate analysis.

The correlation coefficient Spearman's rho $(\rho)$ was used to evaluate whether there are significant relationships between the variables. This nonparametric technique was chosen given that a Likert scale, which is an ordinal scale, was used in the questionnaire. The correlation analysis was performed for the first part of both the financial ratio and Balanced Scorecard sections of the questionnaire.

\subsubsection{Correlation analysis: Financial Ratios}

The results of the correlation analysis for the financial ratios statements are shown in TABLE 5.

TABLE 5: Spearman's correlation coefficient: Financial Ratios

\begin{tabular}{|c|c|c|c|c|c|c|c|c|c|}
\hline & Statement & 1.1 & 1.2 & 1.3 & 1.4 & 1.5 & 1.6 & 1.7 & 1.8 \\
\hline 1.1 & $\begin{array}{l}\text { The use of } \\
\text { financial ratios is } \\
\text { important in } \\
\text { managing a SME }\end{array}$ & 1 & & & & & & & \\
\hline 1.2 & $\begin{array}{l}\text { The use of } \\
\text { financial ratios } \\
\text { by SMEs can help } \\
\text { to improve their } \\
\text { performance }\end{array}$ & $0.761 *$ & 1 & & & & & & \\
\hline 1.3 & $\begin{array}{l}\text { SME managers } \\
\text { have knowledge } \\
\text { on financial } \\
\text { ratios }\end{array}$ & -0.021 & -0.078 & 1 & & & & & \\
\hline 1.4 & $\begin{array}{l}\text { SME managers } \\
\text { need advice on } \\
\text { financial ratios in } \\
\text { order to be able } \\
\text { to use them }\end{array}$ & $0.475^{\star}$ & $0.518 *$ & -0.100 & 1 & & & & \\
\hline
\end{tabular}




\begin{tabular}{|c|c|c|c|c|c|c|c|c|c|}
\hline & Statement & 1.1 & 1.2 & 1.3 & 1.4 & 1.5 & 1.6 & 1.7 & 1.8 \\
\hline 1.5 & $\begin{array}{l}\text { Accountants } \\
\text { have the ability } \\
\text { to provide SME } \\
\text { managers with } \\
\text { advice on } \\
\text { financial ratios }\end{array}$ & $0.538 *$ & $0.512 *$ & 0.010 & $0.511 *$ & 1 & & & \\
\hline 1.6 & $\begin{array}{l}\text { I provide } \\
\text { calculated } \\
\text { financial ratios } \\
\text { to SME managers }\end{array}$ & $0.413 *$ & $0.368 *$ & 0.038 & $0.342 \star$ & $0.485 *$ & 1 & & \\
\hline 1.7 & $\begin{array}{l}\text { I explain the } \\
\text { results of the } \\
\text { financial ratios } \\
\text { to the SME } \\
\text { managers }\end{array}$ & 0.417 * & $0.361 *$ & 0.103 & $0.371^{\star}$ & 0.516 * & 0.896 * & 1 & \\
\hline 1.8 & $\begin{array}{l}\text { I provide advice } \\
\text { or } \\
\text { recommendation } \\
\text { s to SME } \\
\text { managers on how } \\
\text { to improve the } \\
\text { financial ratios }\end{array}$ & $0.458 *$ & $0.422 *$ & 0.081 & $0.309 *$ & $0.481 *$ & $0.815^{\star}$ & 0.831 * & 1 \\
\hline 1.9 & $\begin{array}{l}\text { It will be } \\
\text { beneficial to SME } \\
\text { managers to use } \\
\text { financial ratios in } \\
\text { managing their } \\
\text { business }\end{array}$ & $0.572^{\star}$ & $0.612^{\star}$ & 0.020 & $0.503 *$ & $0.605 *$ & $0.333 *$ & $0.340 \star$ & 0.366 * \\
\hline
\end{tabular}

Source: Authors' calculations

*Correlation is significant at the 0.01 level (2-tailed).

The correlation analysis in TABLE 5 shows that there are significant relationships between all the statements with the exception of statement 1.3. This signifies that a change in statement 1.3 does not affect the other statements, and vice versa. As shown with the univariate analysis in TABLE 2 (refer to the previous section), the respondents disagreed that SME managers have knowledge on financial ratios. In other words, accountants think that SME managers do not have knowledge on financial ratios. The lack of correlation with statement 1.3 indicates that regardless of the respondents' level of agreement on the other statements, they will agree that SME managers do not have knowledge on financial ratios.

There is a significant and very strong positive relationship between statements 1.1 and 1.2 $(\rho=0.761, \rho<.01)$. A respondent who strongly agreed with statement 1.1 would likely also strongly agree with statement 1.2. The results in TABLE 2 show that accountants agree that the use of financial ratios is important to SMEs (statement 1.1). With the strong correlation between statements 1.1 and 1.2 it can be concluded that the use of financial ratios is regarded as important to SMEs because it can help to improve their performance (statement 1.2). The strong positive correlation between statements 1.1 and 1.2 with statement $1.9(\rho=0.572, \rho=0.612$; 
$p<.01)$ confirms that the importance and benefit of using financial ratios in SMEs lies in the potential to improve SMEs' performance.

As shown in TABLE 5, there is a significant and extremely strong positive correlation between statements 1.6 and 1.7, 1.6 and 1.8 and 1.7 and 1.8. The means of these statements (shown in TABLE 2) indicate that accountants calculate financial ratios for SMEs, explain the results and provide advice on how to improve on financial ratios, respectively. The correlation analysis confirms this. The financial ratios calculations will not be provided without explanations or advice, as these solitary calculations will not be of much value to the SMEs.

\subsubsection{Correlation analysis: balanced scorecard}

The results of the correlation analysis for the Balanced Scorecard statements are shown in TABLE 6. As in TABLE 4, only responses from respondents who have heard of the Balanced Scorecard were included in the analysis $(n=108)$. As with the financial ratios statements, there is a strong positive relationship between statements 3.1 and $3.2(\rho=0.799, p<.01)$, but also between statements 3.2 and $3.9(\rho=0.797, \rho<.01)$ and to a lesser extent statements 3.1 and $3.9(\rho=0.720, p<.01)$. A respondent who strongly agreed with statement 3.1 would likely also strongly agree with statements 3.2 and 3.9 (and vice versa). With the strong correlation between these it can be concluded that when the use of the Balanced Scorecard is regarded as important to SMEs, it is because the Balanced Scorecard can potentially help to improve their performance. The benefit and the importance of the use of the Balanced Scorecard in SMEs lie in the potential to improve SMEs' performance.

TABLE 6: Spearman's correlation coefficient: Balanced Scorecard $(n=108)$

\begin{tabular}{|c|c|c|c|c|c|c|c|c|c|}
\hline & Statement & 3.1 & 3.2 & 3.3 & 3.4 & 3.5 & 3.6 & 3.7 & 3.8 \\
\hline 3.1 & $\begin{array}{l}\text { The use of the } \\
\text { Balanced } \\
\text { Scorecard is } \\
\text { important in } \\
\text { managing a SME }\end{array}$ & 1 & & & & & & & \\
\hline 3.2 & $\begin{array}{l}\text { The use of the } \\
\text { Balanced } \\
\text { Scorecard by SMEs } \\
\text { can help to } \\
\text { improve their } \\
\text { performance }\end{array}$ & $0.799 *$ & 1 & & & & & & \\
\hline 3.3 & $\begin{array}{l}\text { SME managers } \\
\text { have knowledge } \\
\text { on the Balanced } \\
\text { Scorecard }\end{array}$ & 0.186 & 0.158 & 1 & & & & & \\
\hline 3.4 & $\begin{array}{l}\text { SME managers } \\
\text { need advice on } \\
\text { the Balanced } \\
\text { Scorecard in order } \\
\text { to be able to use } \\
\text { it }\end{array}$ & $0.557 \star$ & $0.651 *$ & -0.047 & 1 & & & & \\
\hline
\end{tabular}




\begin{tabular}{|c|c|c|c|c|c|c|c|c|c|}
\hline & Statement & 3.1 & 3.2 & 3.3 & 3.4 & 3.5 & 3.6 & 3.7 & 3.8 \\
\hline 3.5 & $\begin{array}{l}\text { Accountants have } \\
\text { the ability to } \\
\text { provide SME } \\
\text { managers with } \\
\text { advice on the } \\
\text { Balanced } \\
\text { Scorecard }\end{array}$ & $0.586 *$ & $0.533 *$ & 0.070 & $0.639 \star$ & 1 & & & \\
\hline 3.6 & $\begin{array}{l}\text { I provide a } \\
\text { Balanced } \\
\text { Scorecard to SME } \\
\text { managers }\end{array}$ & $0.372 *$ & $0.277 \star$ & $0.561 *$ & 0.117 & $0.288 *$ & 1 & & \\
\hline 3.7 & $\begin{array}{l}\text { I explain the } \\
\text { results of the } \\
\text { Balanced } \\
\text { Scorecard to the } \\
\text { SME managers }\end{array}$ & $0.397 *$ & 0.241 * & $0.511 *$ & 0.170 & $0.327 *$ & $0.932 *$ & 1 & \\
\hline 3.8 & $\begin{array}{l}\text { I provide advice or } \\
\text { recommendations } \\
\text { to SME managers } \\
\text { on how to improve } \\
\text { the Balanced } \\
\text { Scorecard results }\end{array}$ & $0.391 *$ & $0.268 *$ & $0.520 *$ & 0.178 & $0.342 *$ & $0.921 *$ & $0.922 *$ & 1 \\
\hline 3.9 & $\begin{array}{l}\text { It will be } \\
\text { beneficial to SME } \\
\text { managers to use } \\
\text { the Balanced } \\
\text { Scorecard in } \\
\text { managing their } \\
\text { business }\end{array}$ & $0.720 *$ & $0.797 \star$ & 0.049 & $0.639 *$ & $0.632 *$ & $0.248 *$ & $0.208 *$ & 0.214 * \\
\hline
\end{tabular}

Source: Authors' calculations

**. Correlation is significant at the 0.01 level (2-tailed).

*. Correlation is significant at the 0.05 level (2-tailed).

Similar to the corresponding financial ratios statements, there is also a significant and extremely strong positive correlation between statements 3.6 and 3.7, 3.6 and 3.8 and 3.7 and 3.8. A respondent who agreed with one of these statements would also agree with the other. The means of these statements (shown in TABLE 4) indicate that most accountants were, however, undecided (neutral) on this topic, and therefore do not develop, explain and provide advice on the Balanced Scorecard. This correlation analysis indicates that in the few cases where accountants do develop a Balanced Scorecard for a SME, they will also explain the results to the SME managers and provide advice on how to improve these results.

\section{CONCLUSION AND RECOMMENDATIONS}

SMEs are very important to the economy (Abor \& Quartey, 2010:223), but they do not perform satisfactorily (Fatoki, 2012:180). Several tools are available to evaluate business performance 
and indicate problem areas, which SMEs can use. According to several studies, SMEs unfortunately do not use these performance measurement tools to their full potential due to a lack of skills and knowledge (Voulgaris et al., 2000:128).

The purpose of this study was to determine whether accountants assist SME managers in South Africa in using performance measurement tools. Two performance measurement tools were chosen for this study: Financial ratios as a traditional (older) tool and the Balanced Scorecard as a modern (newer) tool. The study also sought to determine whether accountants think the use of performance measurement tools, in the form of Financial Ratios or the Balanced Scorecard, can assist SME managers to improve their business management and ultimately their business success.

It can be concluded that the perception is that the use of a performance measurement tool is important in SMEs as it can help to improve their performance and chances of survival. However, accountants feel that SME managers do not have sufficient knowledge regarding performance measurement and need advice on this topic. Accountants therefore calculate, explain and provide advice on the traditional performance measures, financial ratios, to SMEs. They do not develop a Balanced Scorecard, a more modern and strategic performance measurement tool, although they think it might be beneficial to the SMEs.

SME managers do not have the knowledge or skills to successfully use performance measurement tools due to a lack of managerial training (Abor \& Quartey, 2010:225). One might suggest that SME managers enrol for finance courses or managerial workshops, but as small and medium business entrepreneurs they would probably not have sufficient time or finance available in order to formally improve their knowledge and skills. SME managers rather seek advice from professionals. Robson and Bennett (2000:201) found that accountants are the most used source of advice. This finding is supported by the research findings of Berry et al. (2006:38). The most appropriate method to address the problem of a lack of knowledge and skills would be through the help and advice of accountants.

Accountants regard the use of financial ratios as important to SMEs, but feel that SME managers do not have sufficient knowledge to use them. As they regard themselves as able to provide the SMEs with advice and support on this topic, they should attempt to do so to a larger extent than they currently do. This might help SMEs to improve their performance (although only to a small extent) and improve their chances of survival. In turn, this could help SMEs realise their potential as significant contributors to the economy.

This study finds that a lack of knowledge and skills of those providing advice and support to SMEs, in the form of accountants, with specific regard to the Balanced Scorecard, is a further reason for the latter technique not having been implemented. The Balanced Scorecard needs more exposure among accountants and business managers, as it may be worthwhile to use this as a performance management and measurement tool in SMEs. This topic should be included in accounting training programmes, addressing the use, benefits and costs of this tool for large companies as well as small businesses.

This study contributes to the body of knowledge on performance management tools for small businesses. There is however still a large gap in the literature on financial ratios as a management tool in SMEs and the Balanced Scorecard as applied in SMEs. This gap is even more evident in the South African context. This study did not consider in-depth the performance management tools and performance measurement techniques of SMEs, or their reasons and motivation for certain behaviour. Accountants provided only a one-sided view on this topic; the 
views of other accounting and management accounting professionals need to be evaluated in order to determine a more comprehensive picture. Detailed case studies and experimental application of the performance measurement tools in SMEs would be ideal to gather more conclusive and substantial evidence.

Only financial ratios and the Balanced Scorecard were considered in this study. Other performance measurement tools like the strategic measurement analysis and reporting technique (SMART), Cambridge performance measurement design process and the integrated performance measurement tools reference model were not considered. Future research is needed to determine whether these performance measurement tools are used by SMEs and if they could be beneficial to SMEs. Neely et al. (1995:108) also identified the need to clarify whether performance measurement is a luxury for SMEs and which performance measures are of greatest value to them.

\section{LIST OF REFERENCES}

Abor, J. \& Quartey, P. (2010). Issues in SME Development in Ghana and South Africa. Internationa/ Research Journal of Finance and Economics, 39, pp. 218-228.

Ates, A., Garengo, P., Cocca, P. \& Bititci, U. (2013). The development of SME managerial practice for effective performance management. Journal of Small Business and Enterprise Development, 20(1), pp. 28-54.

Banos-Caballero, S., Garcia-Teruel, P.J. \& Martinez-Solano, P. (2010). Working capital management in SMEs. Accounting and Finance, 50(3), pp. 511-527.

Berry, A.J., Sweeting, R. \& Goto, J. (2006). The effect of business advisers on the performance of SMEs. Journal of Small Business and Enterprise Development, 13(1), pp. 33-47.

Cagliano, R., Blackmon, K. \& Voss, C. (2001). Small firms under MICROSCOPE: international differences in production/operations management practices and performance. Integrated Manufacturing Systems, 12(7), pp. 469-482.

Fatoki, 0. (2012). An investigation into the financial management practices of new micro-enterprises in South Africa. Journal of Social Science, 33(2), pp. 179-188.

Ghalayini, A.M. \& Noble, J.S. (1996). The changing basis of performance measurement. International Journal of Operations \& Production Management, 16(8), pp. 63-80.

Gumbus, A. \& Lussier, R.N. 2006. Entrepreneurs use a Balanced Scorecard to translate strategy into performance measures. Journal of Small Business Management, 44(3), pp. 407-425.

Hanif, A. \& Manarvi, I.A. (2010). Investigating the implementation of balanced scorecard in Pakistani small enterprises. 2010 IEEE International Conference on Advanced Management Science (ICAMS), 2, pp. 574-578.

Kamyabi, Y. \& Devi, S. (2012). The impact of advisory services on Iranian SME performance: An empirical investigation of the role of professional accountants. South African Journal of Business Management, 43(2), pp. 61-72.

Kaplan, R.S. \& Norton, D.P. (1996). The Balanced Scorecard: Translating Strategy into Action. Boston: Harvard Business Press. 
Machado, M.J.C.V. (2013). Balanced Scorecard: an empirical study of small and medium size enterprises. Review of Business Management, 15(46), pp. 129-148.

Mewse, D. (2011). Keeping an eye on the health of your business. South African Pharmaceutical Journal, 78(10), pp. 13-15.

National Credit Regulator. (2011). Literature Review on Small and Medium Enterprises'Access to Credit and Support in South Africa. Pretoria, SA: NCR. [Online] Available:

http://www.ncr.org.za/pdfs/Literature\%20Review\%20on\%20SME\%20Access $\% 20$ to $\% 20$ Credit $\% 20$ in $\% 2$ OSouth\%20Africa_Final\%20Report_NCR_Dec\%202011.pdf. (Accessed 30 January 2013).

Neely, A., Gregory, M. \& Platts, K. (1995). Performance measurement system design: A literature review and research agenda. International Journal of Operations \& Production Management, 15(4), pp. 80-116.

Patrone, F. L. \& duBois, D. (1981). Financial ratio analysis for the small business. Journal of Small Business Management, 19(1), pp. 35-40.

Robson, P.J.A. \& Bennett, R.J. (2000). SME Growth: The Relationship with Business Advice and External Collaboration. Small Business Economics, 15(3), pp. 193-208.

Rompho, N. (2011). Why the Balanced Scorecard Fails in SMEs: A Case Study. International Journal of Business and Management, 6(11), pp. 39-46.

Shuttleworth, C.C. (2009). Towards a financial literacy model as a coordinating interface between financial information and decision makers. Unpublished doctoral thesis. Pretoria: University of Pretoria.

Sian, S. \& Roberts, C. (2009). UK small owner-managed businesses: accounting and financial reporting needs. Journal of Small Business and Enterprise Development, 16(2), pp. 289-305.

South Africa. (1962). Income Tax Act, No. 58 of 1962. Government Gazette, 433(22532), pp. 1-70.

South Africa. (2003). National Small Business Amendment Act, No. 26 of 2003. Government Gazette, 461(25763), pp. 2-10.

South African Revenue Service. (2010). More about Small Businesses. [Online] Available: http://www.sars.gov.za/home.asp?pid=46185 (Accessed 12 March 2013).

Thomas, J. \& Evanson, R.V. (1987). An Empirical Investigation of Association between Financial Ratio Use and Small Business Success. Journal of Business Finance \& Accounting, 14(4), pp. 555-571.

Van Wyk, H.A. \& Rossouw, J. (2009). IFRS for SMEs in South Africa: a giant leap for accounting, but too big for smaller entities in general. Meditari Accountancy Research, 17(1), pp. 99-116.

Voulgaris, F., Doumpos, M. \& Zopounidis, C. (2000). On the evaluation of Greek industrial SMEs' performance via multicriteria analysis of financial ratios. Small Business Economics, 15, pp. 127-136. 